\title{
CAN THE RELATION BETWEEN FAT AND PROTEIN IN MILK BE CHANGED BY SELECTIVE BREEDING.
}

\author{
T. LONKA. \\ Agricultural Experiment Station, Department of Animal Breeding. Tikkurila, Finland.
}

Received 15. X. 1946 .

In Finland the feeding of dairy cows is in general so scanty that it does not correspond to their hereditary production capacity. Consequently the yield is considerably smaller than their genotype qualifies them for, in other words, it is less than what they would produce if they were more abundantly fed. In so far as the cultivation of feed plants becomes more effective and efficient, the cattle feeding will naturally improve. In Finland as well as elsewhere at these latitudes in general climatic factors, however, set a certain limit to this improvement. Already in Southern Finland particularly the cultivation of feed plants rich in protein encounters difficulties, which continue to grow as we go northwards to the extent that in Northern Finland proteinous feed plants proper cannot be cultivated to any noteworthy degree. Thus the protein content of feeds produced on farms is in general so low in the greater part of the country that it is not sufficient for satisfying the protein needs of the present high production cows. In earlier years this protein deficiency of the feed produced in the country was compensated by proteinous fodder from abroad, great amounts of which were imported. The experiences got already before the war and especially during it have, however, showed that feeding must be based on the feed produced on the farm even in the event that the use of imported concentrates should at times prove to be very advantageous. Thus under these conditions the low protein content of the feed is the minimum factor restricting production and there are very few possibilities for its removal through the medium of feeding. Therefore the question of what possibilities there are for bettering the situation by means of breeding arises.

Of course the nutrient composition required in the production feed is determined by the milk composition. Thus on the basis of the foresaid it must be observed that the milk composition is not what it should be in our feeding conditions. Namely when taking into consideration the possibilities of Finnish feed cultivation, it would be more advantageous if the protein content of the milk were lower and 
the fat content higher than it is at present. In this case it would be possible to produce more butter-fat, which is so valuable as a nutrient, by means of feed of our own growing. Less of the expensive protein of the feed would be necessary for the production of a kilogram of butter-fat, the production expenses of which would be reduced. This would be of great importance to the households sending their milk to the dairies, in which case only the butter-fat is used for the nourishment of human beings and the other components go to the feeding of animals in the form of skimmed milk. The compensation for the latter does not even come near to covering the production expenses of the substances, particularly the protein, contained in it.

Milk protein is a valuable, and in some cases a necessary, nutrient for both human beings and animals. In this case the protein yield and not its precentage in the milk is in question. The protein yield, again, would not decrease because of the lessening of the protein content as long as the protein of the feed is the minimum factor restricting production, because the cows yielding milk with less protein would produce a correspondingly greater quantity of milk on the home-grown feed. The decrease in protein content would not have a harmful effect on the making of cheese either, for here too the quantity of protein and not the percentage, contained is the main thing. Though the milk protein content should be lower the dairies would continue to get the same quantity of protein as before, and in addition more of the other milk components, which would by no means be disadvantageous in making cheese. From the technical standpoint it is doubtless a matter of no importance whether the same casein quantity is obtained from a greater or smaller amount of milk.

As we mentioned, the abovesaid holds good only if the protein content of the feed is the minimum factor restricting the production. When considerable surplus of cheap protein is available on a farm and the concentration of the feed cannot be increased by means of cultivation, the production of milk richer in protein would be more profitable than that poorer in it. However, cases of this nature will certainly be so rare even in the future that breeding measures cannot be planned according to them. Thus it may be stated that the profitability of our dairy farming would without exception increase, if, by breeding, such cows could be developed whose milk would along with a high butter-fat content contain less protein than now.

Is it possible to develop dairy cattle in this direction?

The following equations given by several investigators in which $\mathrm{p}=$ protein percentage and $\mathrm{f}=$ fat percentage indicate the dependence of the protein content on the fat content.

$\begin{array}{ll}\text { Timpe (7) } & \mathrm{p}=2+0.35 \mathrm{f} \\ \text { Hansson (4) } & \mathrm{p}=1.94+0.33 \mathrm{f} \\ \text { Andersen and Langmack }(1) & \mathrm{p}=1.597+0.446 \mathrm{f} \\ \text { Poijärvi and Listo (5) } & \mathrm{p}=2.07+0.28 \mathrm{f} \\ \text { Gaines (2) } & \mathrm{p}=(1.46+0.40 \mathrm{f}) \pm 0.19 \\ \text { Gaines and Overman }(3) & \mathrm{p}=(2.10+0.346 \mathrm{f}) \pm 0.085 \\ \text { Pressler }(6) & \mathrm{p}=0.92+0.64 \mathrm{f}\end{array}$


It can be seen from the equations that the protein percentage of the milk increases as the fat percentage increases. In the equations presented by the several investigators the regression between the fat and protein percentages varies greatly, but in general the increase of the protein percentage has been under 0.5 of the corresponding increase in fat percentage. According to this consequently there is in milk to one kilogram of fat the less of protein the higher the fat percentage of milk. Thus for instance according to PoIJäRvi's and Listo's equations there is $798 \mathrm{~g}$. of protein to one kilogram of fat in milk of $4 \%$ fat content, and in $5 \%$ milk only $694 \mathrm{~g}$. Therefore in 4-per cent milk there is $104 \mathrm{~g}$. or 13 per cent more of protein per kilogram of fat than in the 5-per cent milk. Many cattle breeders have, in fact, taken advantage of this phenomenon for a long time already and have chosen cows producing milk as rich in fat as possible for breeding. In this way they have striven towards the same goal as that presented above, in other words, they have endeavored to develop cows having a composition of milk that would correspond to our feeding conditions better than before. This selection of course has been influenced also by the fact that the total net energy amount needed in producing milk rich in fat is smaller per kilogram of fat than in milk poorer in fat, in which the amount of other components, less valuable commercially, is greater.

On the condition that the relation between the fat and protein contents in milk is not constant but varies with different animals, it would be incomparably more effective if in breeding high fat percentage would be coupled with low protein percentage.

Does the protein percentage of the milk of different cows vary independently of the fat percentage, in other words, is the protein content of the milk of cows producing an equal fat content variable, and is this variation so great that the relation between the fat and protein percentages of the milk could be changed by means of breeding in the direction in question? These are the questions which we shall endeavour to answer.

\section{The Relation between Fat and Protein in Milk of Different Cows.}

The possibilities of developing some characteristic can be estimated on the basis of the individuals differing from the average and particularly of those differing most. For this purpose the characteristics in question of so many animals must be known that we may presuppose that cows possessing even the rarest gene combinations will be found. For the time being material suitable for the investigation of the interrelation between the fat and protein percentage of milk is comparatively small. For the protein percentage of cow's milk has been determined relatively seldom, and even less frequently have milk analyses been made on the basis of which the protein percentage of milk characteristic of the cow in question would be found out in the same way as the average fat percentage is estimated. This entails several protein analyses during a lactation, from which first the protein yield is calculated for the lactation, and then on the basis of this value and the 
milk yield of the lactation the mean protein percentage for the whole period is computed.

Owing to the fact that important general rules with respect to feeding have been the aim of milk analyses the milk samples have been collected from cows at different production stages without any effort to determine the mean protein percentages of the milk of individual cows. Though complete answers to the questions at hand cannot be got on the basis of the results from such analyses, their diversity, nevertheless points to the fact that the relation between the fat and protein percentages of the milk of the several individuals is different. Thus for instance in PoIJÄRVI's and Listo's (5) material comprising 88 milk samples, on the grounds of which they have evolved the above cited equation, the separate results of the analyses differ so much from the general rule that investigators doubt the possibilities of using the average formula.

As a matter of fact, the difference between individual cows is clearly distinguishable in the investigations, in which several analyses have been made of the milk of the same cow with the result that a more distinct picture can be obtained of the fat and protein percentages characteristic of each cow. The most exhaustive and comprehensive of the investigations at the disposal of the author is the one by Gaines and Overman (3) covering 130 cows of different breeds (14 Ayrshire, 17 Brown Swiss, 14 Guernsey, 15 Holstein, 13 Jersey, 21 Guernsey-Holstein $F_{1}$, Guernsey-Holstein $\mathrm{F}_{2}$ and 11 Guernsey-Holstein Back-Cross). These writers have analyzed the milk of the test cows belonging to the same herd during $1-3$ lactations at intervals of five weeks. Each sample has been a composite one from the milk yield of three days. On the basis of the analysis results obtained in this way they have estimated for each cow the mean protein and fat percentages of the milk yield of a lactation or, more accurately speaking, of 305 days. A comparatively great correlation has been got between the fat and protein contents of milk according to these percentages, for the correlation coefficients is +0.755 . This correlation coefficient which has been obtained from the whole material is somewhat greater than that which is got from most of the breeds of their material separately. In making calculations on the basis of the results obtained by these authors slightly larger correlation coefficients $(0.84$ and 0.88$)$ are got only from Guernsey and Jersey cows, whereas the corresponding values of the other breeds are smaller varying from 0.43 to 0.68 . It is particularly the correlation coefficients got from each breed separately which are of importance in this connection, because breeding is practiced only within the circle of the same breed. Moreover it is to be noted, as we have mentioned above, that breeding possibilities cannot be judged solely on the basis of average characteristics as for instance correlation coefficients, but primarily on the basis of the animals which differ most from the average. When this fact is studied in the material referred to, it is observed that protein percentages of individual cows having the same fat percentages in many cases differ very greatly from one another. Thus, for instance, the protein contents of the milk of Ayrshire cows possessing the same fat percentage differs in extreme cases about 0.5 per cent. This is a great deal when we take into consideration that the protein 
percentage of the Ayrshire cows varies only 0.64 per cent in the whole material. The case is approximately the same with respect to Holstein cows, for the protein percentage of the cows having the same fat percentage differs in extreme instances about 0.65 per cent while the protein percentage for the whole Holstein material only varies $2.97 \%-3.73 \%$ or 0.76 per cent. The divergency is not exactly as great in the other breeds, but nevertheless it is great enough to indicate that it cannot in these any more than in the former two breeds be solely due to external factors, but that also genetic factors must affect it. PRESSLER's (6) investigations also point to this primarily for the reason that the correlation and regression computed for each cow from the analysis results has been very different for the individual cows.

Although the above-mentioned investigations as well as others show that the protein percentage varies independently of the fat percentage, they are however so few in number and comprise such a small number of cows that the breeding measures referred to above cannot yet be planned on the basis of them. Especially the milk composition of the Finnish native cow specifically with respect to protein may have become different from that of other breeds, because in earlier decades and partly also later it has lived under very different feeding conditions than the livestock of other countries. The author of this paper has endeavoured to answer the question at hand for the reason that it is of vital importance to Finnish cattle breeding. These investigations have as yet been only a preparation for later extensive ones, and no farreaching conclusions can be drawn on the basis of them. But since they throw light on the question for their own part the author has considered it justifiable to give some advance information with regard to them.

\section{The Relation between Fat and Protein in Milk of West-Finnish Native Cows}

The material comprises 54 West-Finnish native cows from four herds owned by the state. The analyses with respect to the cows belonging to two of the herds have been made in 1940 and 1941 and those with respect to the cows the two other in 1945 and 1946. The aim has been to choose those cows of the herds which calve in the latter half of the year so that the variation in feeding due to change of seasons would not be able to affect the results. Nevertheless, for the purpose of increasing the material 9 cows which have calved at the beginning of the year were included.

The milk yield of the test animals has been determined by weighing the cow's milk yield for a day three times a month at intervals of ten days. The determining of the fat and protein percentage, however, has been done only once a month from one of the test milkings. The fat analysis has been made by means of the Gerber method, and in the protein analysis the total nitrogen of the milk has been determined by the Kjeldahl method first and then the protein was got by multiplying this figure by 6.37 .

When in conformance with the practice of most of the earlier investigators the correlation and regression coefficients for the fat and protein percentages 
of the milk are computed on the basis of all the single analysis results (547 analyses), we derive the following values, when fat percentage $=\mathrm{x}$ and protein percentage $=\mathrm{y}$.

$$
\mathrm{r}=+0.57 \pm 0.03 \quad \mathrm{R}_{\mathrm{x} / \mathrm{y}}=+0.80 \pm 0.05 \text { and } \mathrm{R}_{\mathrm{y} / \mathrm{x}}=+0.41 \pm 0.03
$$

and the following equation expressing the correlation between fat and protein percentages

$$
\mathrm{y}=1.55+0.41 \mathrm{x} .
$$

\begin{tabular}{|c|c|c|c|c|c|c|c|c|c|c|c|c|c|c|c|c|}
\hline \multirow{2}{*}{ Herds } & \multicolumn{16}{|c|}{ Production months } \\
\hline & 1 & 2 & 3 & 4 & 5 & 6 & 7 & 8 & 9 & 10 & 11 & 12 & 13 & 14 & 15 & 16 \\
\hline \multicolumn{17}{|l|}{ Viikin Latokartano } \\
\hline Fat $\%$ & 4.27 & 4.31 & 4.35 & 4.36 & 4.45 & 4.53 & 4.66 & 4.84 & 4.81 & 5.13 & 4.94 & 5.53 & 5.23 & 5.20 & 5.55 & 4.50 \\
\hline Protein \% & 3.49 & 3.27 & 3.41 & 3.41 & 3.35 & 3.39 & 3.59 & 3.67 & 3.75 & 3.90 & 4.07 & 4.44 & 4.47 & 4.07 & 3.86 & 3.51 \\
\hline Milk, kg & 412 & 571 & 472 & 457 & 425 & 381 & 359 & 308 & 277 & 296 & 262 & 254 & 264 & 292 & 254 & 299 \\
\hline Number of obs. & 14 & 13 & 12 & -14 & 14 & 12 & 14 & 14 & 13 & 9 & 8 & 4 & 3 & 2 & 2 & 1 \\
\hline \multicolumn{17}{|l|}{ Malminkartano } \\
\hline Fat $\%$ & 4.54 & 4.23 & 4.32 & 4.35 & 4.40 & 4.39 & 4.48 & 4.49 & 4.70 & 4.68 & 5.05 & 6.00 & 5.07 & 4.90 & 4.70 & 5.50 \\
\hline Protein \% & 3.49 & 3.24 & 3.26 & 3.35 & 3.39 & 3.33 & 3.54 & 3.53 & 3.74 & 3.71 & 4.29 & 4.18 & 4.55 & 4.45 & 4.53 & 5.15 \\
\hline Milk, kg & 486 & 492 & 447 & 428 & 380 & 354 & 324 & 288 & 219 & 188 & 159 & 160 & 141 & 192 & 144 & 65 \\
\hline Number of obs. & 21 & 19 & 21 & 21 & 21 & 20 & 21 & 21 & 20 & 13 & 6 & 4 & 3 & 1 & 1 & 1 \\
\hline \multicolumn{17}{|l|}{ Nuorisovankila } \\
\hline Fat $\%$ & 4.17 & 3.86 & 3.95 & 4.08 & 4.23 & 4.50 & 4.66 & 4.95 & 5.10 & 5.00 & 4.30 & & & & & \\
\hline Protein \% & 3.24 & 2.89 & 2.85 & 2.89 & 2.92 & 3.07 & 3.20 & 3.58 & 3.90 & 3.63 & 3.68 & & & & & \\
\hline Milk, kg & 427 & 391 & 368 & 309 & 295 & 266 & 215 & 170 & 140 & 211 & 301 & & & & & \\
\hline Number of obs. & 11 & 11 & 11 & 11 & 11 & 11 & 11 & 10 & 7 & 3 & 2 & & & & & \\
\hline \multicolumn{17}{|l|}{ Samma'isto } \\
\hline Fat $\%$ & 4.51 & 4.06 & 4.03 & 4.16 & 4.31 & 4.25 & 4.26 & 4.28 & 4.62 & 5.02 & 4.88 & 5.00 & & & & \\
\hline Protein \% & 4.40 & 2.85 & 2.91 & 2.96 & 3.03 & 3.03 & 3.00 & 3.07 & 3.26 & 3.40 & 3.72 & 3.98 & & & & \\
\hline Milk, kg & 269 & 411 & 375 & 345 & 308 & 287 & 277 & 274 & 271 & 237 & 184 & 76 & & & & \\
\hline Number of obs. & 8 & 8 & 8 & 8 & 8 & $\cdot 8$ & 8 & 8 & 6 & 6 & 6 & 4 & & & & \\
\hline \multicolumn{17}{|l|}{ Total } \\
\hline Fat $\%$ & 4.39 & 4.14 & 4.20 & 4.27 & 4.37 & 4.42 & 4.53 & 4.64 & 4.79 & 4.91 & 4.90 & 5.51 & 5.15 & 5.10 & 5.27 & 5.00 \\
\hline Protein \% & 3.43 & 3.11 & 3.15 & 3.21 & 3.23 & 3.24 & 3.40 & 3.50 & 3.69 & 3.72 & 4.00 & 4.20 & 4.51 & 4.20 & 4.08 & 4.33 \\
\hline Milk, kg & 426 & 439 & 452 & 403 & 372 & 333 & 394 & 271 & 231 & 232 & 208 & 163 & 203 & 259 & 217 & 182 \\
\hline Number of obs. & 54 & -51 & 52 & 54 & 54 & 51 & 54 & 53 & 46 & 31 & 22 & 12 & 6 & 3 & 3 & 2 \\
\hline
\end{tabular}

Table I. Fat and Protein Percentage of the Mitk and the Milk Yield during the Different Months of Lactation.

In this investigation too, just as in all the earlier ones the correlation is linear, wherefore the coefficients of correlation and regression give a correct picture of the mean interrelation between the characteristics in question. The said correlation is slightly greater as compared to PoIJ ÄRvi's and Listo's (5) results, but it is about the same as that in foreign investigations, the same pertaining to the equation too.

During the lactation the fat and protein contents in the several herds have changed as shown in Table and Figure 1.

The mean percentages of fat and protein for each farm separately and for all of them together as well as the milk yields of the different production months are 


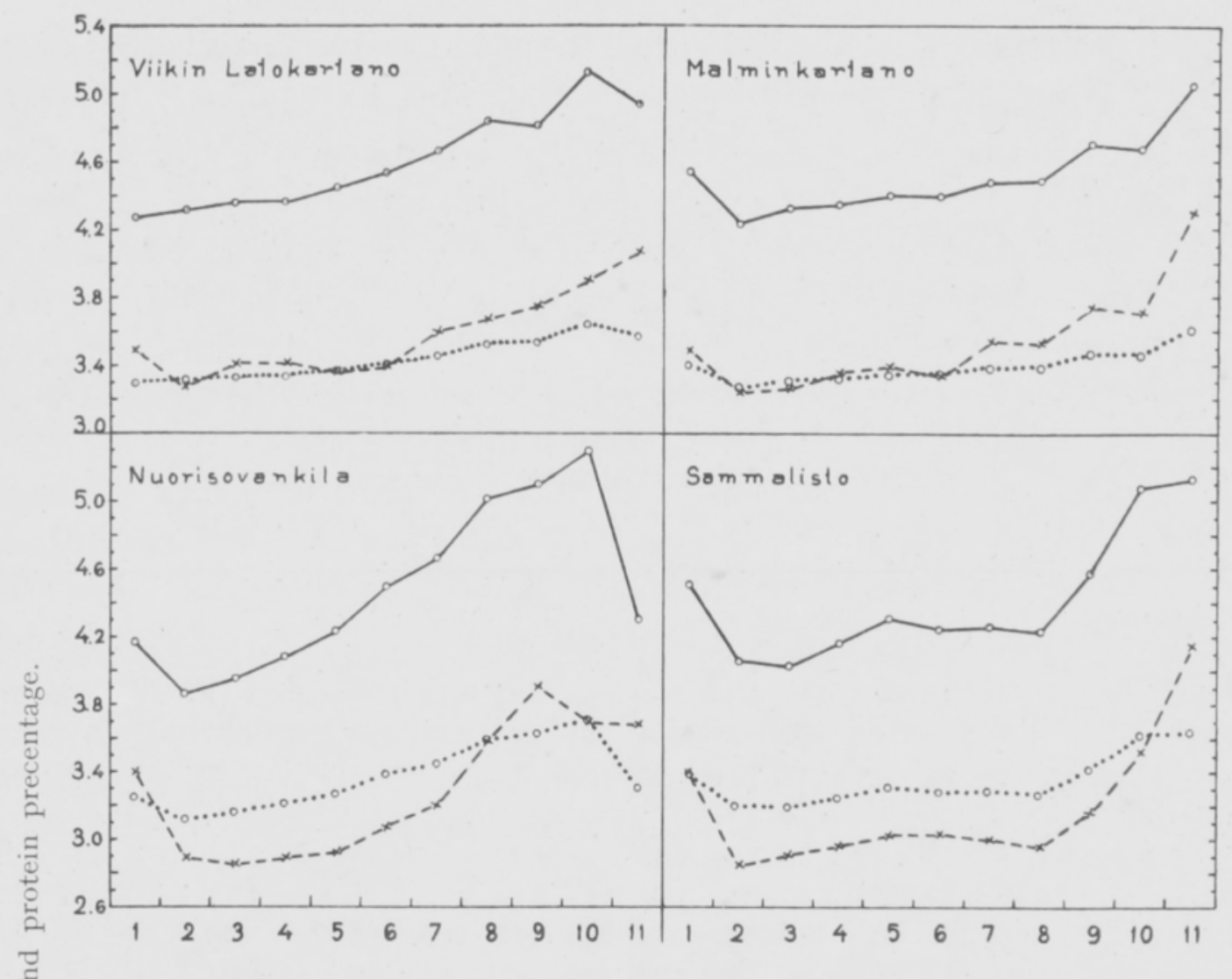

$$
\text { 压 }
$$

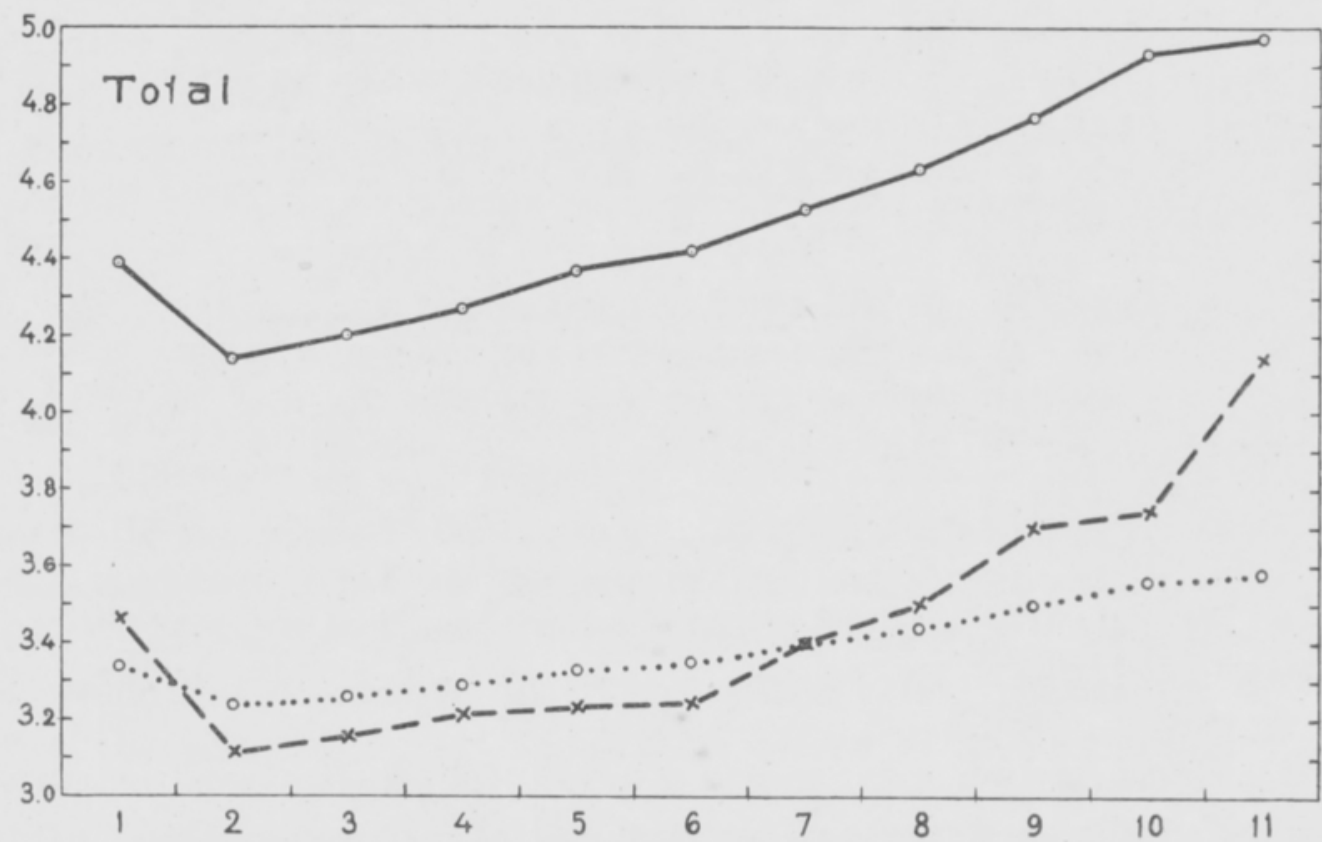

Production month

Figure $I$. The fat and protein percentage of the milk of the different month of lactation.

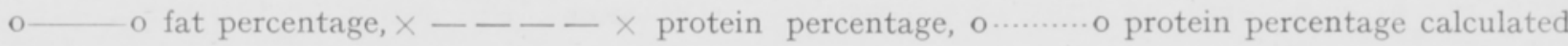
from the equation. $y=1.55+0.41 x$ on the basis of the fat percentage.

given in the Table 1. A few of the cows have had udder inflammation on one of the test days. The analysis results obtained then have not been taken into consideration in calculating the results in Table 1 . Therefore the number of obser- 
vations at the beginning of the lactation, when all the cows were lactating, is not so great for every test as the number of cows.

The diagrams of Figure 1 give the most distinct idea of the change in the fat and protein contents during the lactation. We can see that the fat and protein contents of the milk increase at the end of the lactation, what is generally known. Whereas it is surprising that the protein percentage increases somewhat more sharply than the fat percentage. According to the results of the other authors referred to as well as all the analysis results above the protein content should on the contrary increase less than the fat content. This can be seen also from the dotted line of the figure, which has been got by calculating the protein percentage from the above-mentioned equation $\mathrm{y}=1.55+0.41 \mathrm{x}$ on the basis of the fat percentage. The real protein percentages differ very greatly from the protein percentages calculated on the basis of the fat percentages. A result of this kind is not characteristic only of the material at hand, for e.g. Pressler's (6, p. 41) diagrams are similar to the above. This being the case, the regression equations would not give even approximately correct protein contents of the different months of the lactation, but different regression equations would have to be derived for the different periods of the lactation.

Since the relation between the fat and protein percentage changes during the lactation, the mean value of this relation is at least to some extent dependent on the length of the calving interval. Therefore, in determining the averages of the fat and protein percentages of the individual cows, the results of the eighth and subsequent production months have not been taken into consideration. Drawing the line depends, of course, to a great extent upon interpretation. Perhaps the eight and even the ninth month might be included without the calving interval having any greater effect on the final results. Since, on the other hand, there is reason to strive to eliminate as carefully as possible the influence of external factors causing variation and since drawing the line so low as in above causes no disturbance, the writer has come to this decision. Also the fact that in this way all the results date from indoor feeding carried weight in the matter. When using the results of the earlier part of the lactation slightly lower values for the fat and protein percentages are derived than those with respects to the whole lactation, but this has no significance in this connection.

During the first weeks of the lactation the fat and protein percentage of the milk is slightly higher than later, as we can see from the diagram above. Since on the other hand the fat and protein analyses have been made on specified days of the month (on different days on the several farms), the value of the first analysis result depends to a certain extent on what day of the month the cow has calved. For this reason also the first analysis results have been omitted in the averages of the cows. Thus the mean fat and protein percentage of the milk of individual cows has been computed only from the analysis results of $2-7$ production months. These averages are so-called "weighed", that is they have been calculated on the basis of the quantity of fat and protein contained in the milk yield of the cow 
during the period mentioned and not directly from the fat and protein percentages of these months.

Figure 2 has been derived from the averages of the production months of the individual cows computed as explained above.

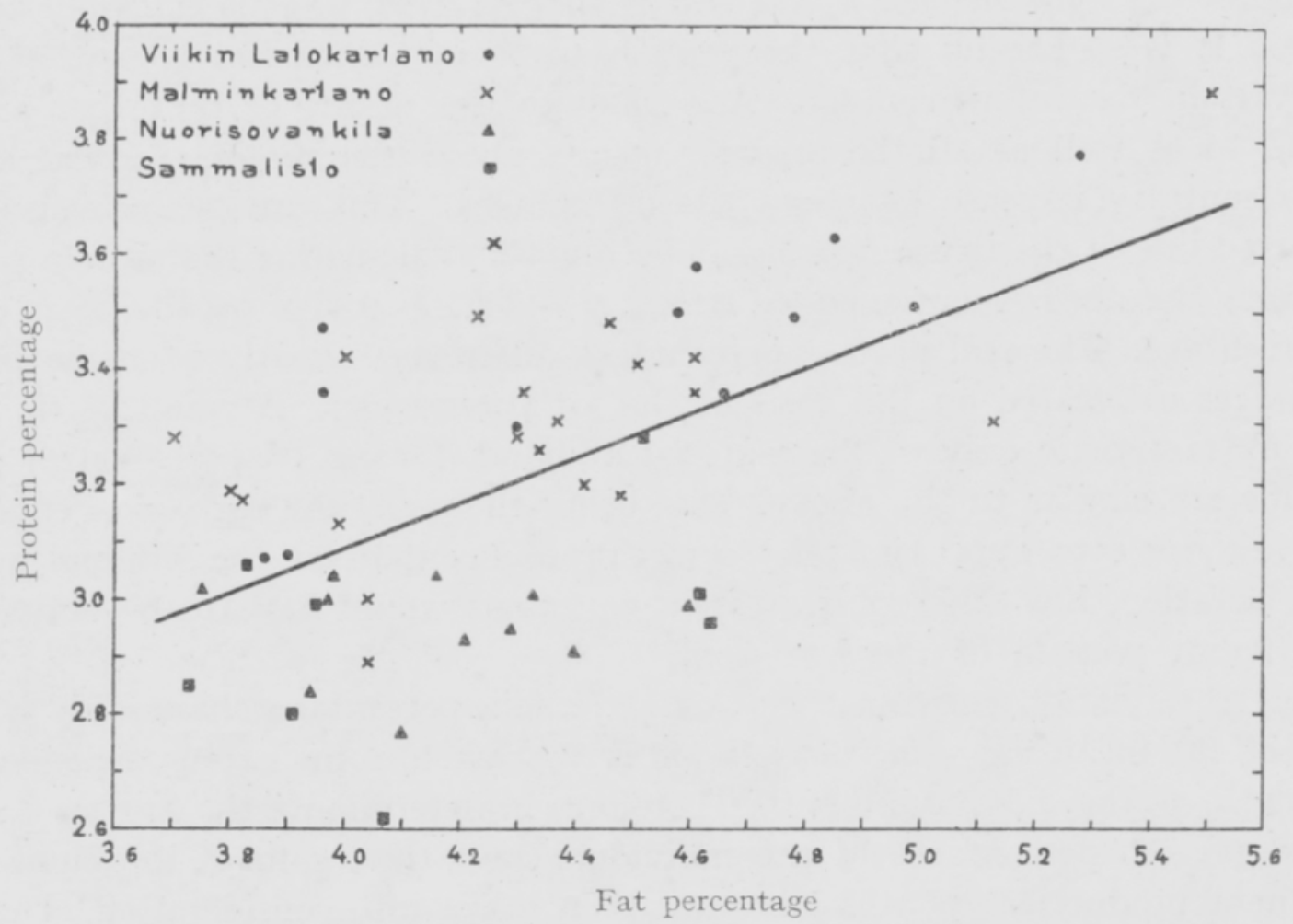

Figure 2. Averages of fat percentage and protein percentage during the 2 to 7 months of lactation of 64 cows (The correlation coefficient is $\mathrm{r}=+0.60 \pm 0.09$ and regression equation $\mathrm{y}=1.53+0.39 \mathrm{x}$ ).

In this figure the values of the cows of the different farms are indicated by means of different signs. The coefficients of correlation and regression have also been calculated from these results. The following values were obtained for the latter

$$
\mathrm{r}=+0.60 \pm 0.09, \quad \mathrm{R}_{\mathbf{x} / \mathbf{y}}=0.93 \pm 0.17 \text { and } \mathrm{R}_{\mathbf{y} / \mathbf{x}}=0.39 \pm 0.07
$$

in which $\mathrm{x}=$ fat percentage and $\mathrm{y}=$ protein percentage. As we can see from the figure, the correlation is rectilinear and the regression equation expressing it is

$$
\mathrm{y}=1.53+0.39 \mathrm{x},
$$

which is indicated by the straight line in the figure. The coefficient of correlation is about as great as the corresponding coefficients derived by GAINES and OvERMAN from the different breeds. In this material too as in that of these authors there are several individuals whose protein percentage diverges to a considerable extent from the value presupposed by the fat percentage. Table 2 has been drawn up because these extreme divergencies have a special significance in estimating breeding possibilities. In addition to the protein contents derived from the material and estimated from the equation the extreme divergencies in each fat content class have been given in the table. These divergencies have been calculated by 
subtracting in each fat percentage class in plus and minus direction the value derived from the equation from the values of the individuals diverging most. Figures corresponding to those computed from the protein percentages have also been calculated for the amount of protein per butter-fat kilogram.

Table 2. The protein percentage and protein yield of the milk of individual cows per kilogram of fat in the different fat percentage classes as well as the extreme divergencies from the values derived from the regression $(y=I .53+0.39 x)$.

\begin{tabular}{|c|c|c|c|c|c|c|c|c|c|}
\hline \multirow{2}{*}{$\begin{array}{c}\text { Fat } \\
\text { percentage }\end{array}$} & \multirow[b]{2}{*}{ Cows } & \multicolumn{4}{|c|}{ Protein percentage } & \multicolumn{4}{|c|}{ Protein in grams per $\mathrm{kg}$. fat } \\
\hline & & $\begin{array}{c}\text { From the } \\
\text { material }\end{array}$ & $\begin{array}{l}\text { Accoring } \\
\text { to equa- } \\
\text { tions }\end{array}$ & $\begin{array}{r}\text { Extr } \\
\text { diverg }\end{array}$ & $\begin{array}{l}\text { reme } \\
\text { yencies }\end{array}$ & $\begin{array}{l}\text { From the } \\
\text { material }\end{array}$ & $\begin{array}{c}\text { According } \\
\text { to equa- } \\
\text { tions }\end{array}$ & $\begin{array}{r}\text { Extr } \\
\text { diverg }\end{array}$ & $\begin{array}{l}\text { reme } \\
\text { rencies }\end{array}$ \\
\hline $3.7-3.8$ & 3 & 3.05 & 2.99 & +0.26 & -0.14 & 813 & 797 & +69 & -37 \\
\hline $3.8-3.9$ & 4 & 3.10 & 3.03 & +0.12 & -0.02 & 805 & 787 & +31 & +5 \\
\hline $3.9-4.0$ & 10 & 3.09 & 3.07 & +0.38 & -0.22 & 782 & 777 & +96 & -56 \\
\hline $4.0-4.1$ & 5 & 3.03 & 3.11 & +0.34 & -0.46 & 748 & 768 & +84 & -114 \\
\hline $4.1-4.2$ & 2 & 2.90 & 3.15 & -0.10 & -0.40 & 699 & 759 & +24 & -96 \\
\hline $4.2-4.3$ & 4 & 3.25 & 3.19 & +0.46 & -0.24 & 765 & 751 & +108 & -56 \\
\hline $4.3-4.4$ & 6 & 3.27 & 3.23 & +0.12 & -0.18 & 752 & 743 & +28 & -41 \\
\hline $4.4-4.5$ & 4 & $3.3)$ & 3.27 & +0.18 & -0.32 & 719 & 735 & +40 & -72 \\
\hline $4.5-4.6$ & 3 & 3.42 & $3.3)$ & +0.25 & -0.05 & 752 & 725 & +55 & -11 \\
\hline $4.6-4.7$ & 7 & 3.24 & 3.34 & +0.21 & -0.39 & 697 & 718 & +45 & -84 \\
\hline $4.7-4.8$ & 1 & 3.45 & 3.38 & +0.07 & & 726 & 712 & +15 & \\
\hline $4.8-4.9$ & 1 & 3.65 & 3.42 & +0.23 & & 753 & 705 & +47 & \\
\hline $4.9-5.0$ & 1 & 3.55 & 3.46 & +0.09 & & 717 & 699 & +48 & \\
\hline $5.0-5.1$ & - & - & 3.50 & & & - & 693 & & \\
\hline $5.1-5.2$ & 1 & 3.35 & 3.54 & & -0.19 & 650 & 687 & & -37 \\
\hline $5.2-5.3$ & 1 & 3.75 & 3.58 & +0.17 & & 714 & 682 & +32 & \\
\hline $5.3-5.4$ & - & - & 3.62 & & & - & 677 & & \\
\hline $5.4-5.5$ & - & - & 3.66 & & & - & 672 & & \\
\hline $5.5-5.6$ & 1 & 3.85 & 3.69 & +0.16 & & 694 & 665 & +29 & \\
\hline
\end{tabular}

We can see from the extreme divergencies of the protein percentage in question that the protein percentage of the milk of cows producing equally fat-rich milk may be very different. There are in the material cows whose protein percentages diverge nearly $0.5 \%$ from the mean value. This must be held to be a very great variation when taking into consideration that the protein percentage in the whole material varies only between 2.6 and 3.92 or a little over one per cent, in other words, only a little more than what the extreme values of protein percentages diverge in the same fat percentage class. In addition it must be remembered that only with respect to 54 cows of the four herds have we advance information of the relation between the fat and protein percentages of the milk, and that the herds as well as the cows have been selected at random as regards this fact. Thus it is evident that in such a material not the greatest possible divergencies from the general rule are to be found, but that they must be considerably greater than those presented here. 
The cows belonging to the highest fat percentage classes, in which the divergencies of protein percentages have the greatest significance from the standpoint of breeding, differ comparatively little from the average. This is doubtless primarily due to the fact that there are so few animals in these classes that greater divergencies from the average do not happen to appear among them. For there is no reason to surmise that variation in protein percentage of cows producing especially fatrich milk should be smaller than that of those producing milk less rich in fat. This is indicated also by the fact that in as high a fat percentage class as 4. $6-4$. 7. the greatest divergency from the average is about $0.4 \%$. And it may indeed be said with tolerable certainty that the protein percentage of the milk of the West-Finnish native cows varies independently of the fat percentage at least about one per cent.

The significance of the variation in question becomes clearer when we study how it is manifested in the quantity of protein yield. The greatest divergencies in the material are, as we see from the table 2 , about $110 \mathrm{~g}$ from the average plus and minus or over $200 \mathrm{~g}$ per kilogram of fat. Taking the above-mentioned one per cent divergency in protein percentage as the basis of calculation we get an about $250 \mathrm{~g}$ or $31 \%$ divergency in the protein quantity in the lowest, $3.7-3.8 \%$ fat percentage class and about $180 \mathrm{~g}$ or about $27 \%$ in the highest, $5.5-5.6 \%$ class. Therefore in the yield of one of two cows producing equally fatrich milk there can be $180-250 \mathrm{~g}$ or $27-31 \%$ less protein per kilogram of fat than in the milk yield of the other.

Naturally a part of the divergency in the protein percentage is caused by feeding or some other external factors. Nevertheless there is reason to note that for instance the above material is collected only from four herds, whose feeding and care has been practically the same. As it has been explained above (p. 00), an effort has been made to lessen the divergencies caused by other external factors too, such as season and calving interval by selecting cows calving in the autumn for the tests and by taking into consideration only the results of $2-7$ production months. Thus there is reason to suppose that the effect of the external factors is not great, but that the greater part of the divergencies appearing in the material between individual animals is due to the difference in their genotypes.

\section{Conclusions}

In Finland the protein content of the feeds is in general so low that it restricts the milk yield particularly in herds of high production capacity. This is especially significant for the reason that owing primarily to climatic factors the quality of the feeds cannot be notably improved in this respect. Therefore an effort should be made to change the composition of milk by means of breeding in such a way that it would correspond to the possibilities of feed cultivation in Finland better than at present. This would mean that it should be endeavoured to breed cows whose milk is very fat-rich but at the same time poor in protein, in which case more of the commercially valuable butterfat could be produced on the feed grown on the estate. Since a correspondingly greater amount of milk of poor protein 
percentage could be produced than that of protein rich milk, the breeding of such cows would not decrease the yield of protein, which is of such great food value, but as great an amount in kilograms of milk protein would be available as earlier for domestic purposes as well as dairies.

We have aimed at this goal in our country in general by endeavouring to raise the fat percentage of the milk by means of breeding. It is known that protein percentage does not increase exactly as markedly as the fat percentage, wherefore the protein yield per kilogram of fat decreases as the percentage rises. The influence of breeding would however be incomparably greater if low protein percentage were selected simultaneously with high fat percentage. In the investigation we have dealt with the possibilities of such selection in Finnish cattle, in connection with which we have striven to make clear how much the protein percentage of the milk varies independently of the fat percentage.

The material comprises 54 West-Finnish Native cows; the fat and protein percentages of their milk yield has been determined once a month during one lactation. The relation of fat and protein is not the same throughout the whole lactation, but it changes so that at the end of the lactation the protein percentage as compared with the fat percentage is relatively greater than at the beginning of the period (Table and Figure 1). The averages of the fat and protein percentages and likewise the correlation between them depend consequently upon the length of the calving interval. Therefore the said averages have been estimated only on the basis of $2-7$ production months. Fy means of these averages $r=+0.60 \pm 0.09$ was derived as the coefficient of correlation between the fat and protein percentages $\mathrm{y}=1.53+0.39 \mathrm{x}$ as the regression equation, $\mathrm{x}=$ fat percentage and $\mathrm{y}=$ protein percentage.

The individual cows diverge very much frcm the general rule set by the regression equation, which can be concluded already frcm the ccmparatively low value of the coefficient of correlation. The protein percentage of the milk yield of the WestFinnish Native cows diverges at least about one per cent independently of the fat percentage when judging on the basis of the extreme divergencies in the material. Although a part of the divergency evidently is caused by external factors, the role of the genetic factors is nevertheless so great that there appear to be great possibilities for breeding cows producing fat-rich milk by means of breeding but having a protein percentage which would be considerably lower than the present average.

\section{Acknowledgement}

I am greatly indebted to Professors P. Tuorila and I. Poljärvi, Mr. P. Haulio, M. A. and Mr. A. Mäkelä, M. A., Mr. E. Barkoff, C. E., Mr. O. I. Osara M. A. and Messrs. E. Erho and O. Himdenheimo, with whose valuable assistance and support the carrying out of the investigation has been possible.

I wish also to express my warm gratitude to Suomen Kulttuurirahasto, which has granted a stipend for the research. 


\title{
REFERENCES.
}

(1) Andersen, A. G. and Langmack, P. V. F. P. Undersøgelser over den danske Komaelks genomsnittelige sammansaetning. Beretning fra Forsøgslaboratoriet, 113, 1923.

(2) Gaines, W. L. Relative rates of secretion of various milk constituents. Jour. of Dairy Sci., 8 p. $486-496,1925$.

(3) Gaines, W. L. and Overman, O. R. Interrelations of milk-fat, milk-protein and milk-energy yield. Jour. of Dairy Sci., 21, p. 261-271, 1938.

(4) Hansson, N. Kan man med ekonomisk fördel höja medelfetthalten i den af våra nötkreatursstammar och raser lämnade mjölken? Kungl. Lantbruksakademiens Handlingar och Tid. skrift, 52, p. $289-369,1913$.

(5) Poijärvi, I. and Listo, Elsa-Maija Suomessa tuotetun lehmänmaidon kokoomuksesta ja lehmien siitä johtuvasta tuotantorehuntarpeesta. Referat: Über die Zusammensetzung der in Finland produzierten Kuhmilch und den dadurch bedingten Bedarf der Kühe an Produktionsfutter. Valtion maatalouskoetoiminnan julkaisuja 28, pp. 50. Helsinki 1930.

(6) Pressler, H. Untersuchungen über die Beziehungen zwischen Fett und Eiweiss in der Milch schwarzbunter Tieflandrinder. Diss. Bonn, 1937.

(7) Timpe, H. Gesetzmässigkeiten in der Zusammensetzung der Kuhmilch und der Nachweiss von Verfälschungen derselben. Ref: Zeitschrift f. Untersuchung d. Nahrungs- und Genussmittel, 3, p. $339-340,1900$.

\section{SELOSTUS \\ VOIDAANKO RASVAN JA VALKUAISEN SUHDETTA MAIDOSSA MUUTTAA SIITOSVALINNALLA?}

\author{
T. LONKA. \\ Maatalouskoelaitos, Kotieläinjalostusosasto, Tikkurila.
}

Suomessa on rehujen valkuaispitoisuus yleensä niin alhainen, että se huomattavassa määrässä rajoittaa maidontuotantoa varsinkin korkeatunttoisissa karjoissa. Tämä on erityisen merkityksellistä, koska lähinnä ilmastollisista seikoista johtuen, ei rehujen laatua voida tässä suhteessa sanottavasti parantaa. Sen vuoksi olisi syytä pyrkiä siitosvalinnalla muuttamaan maidon kokoomusta siten, että se nykyistä paremmin vastaisi Suomessa mahdollista rehuviljelystä. Tämä tarkoittaa, että olisi pyrittävä kehittämään lehmiä, joiden maito olisi hyvin rasvapitoista, mutta samalla valkuaisköyhää, jolloin kotoisilla rehuilla voitaisiin tuottaa entistä enemmän kaupallisesti arvokasta voirasvaa. Koska valkuaisköyhää maitoa olisi mahdollista tuottaa vastaavasti enemmän kuin valkuaisrikasta, ei mainittu toimenpide vähentäisi karjasta saatavaa maidon valkuaisen määrää, vaan olisi sekä kotitalouteen, että juustonvalmistukseen saatavissa yhtä suuri kilomäärä maidon valkuaista kuin aikaisemminkin.

Meikäläisten karjanjalostajien pyrkimyksenä on tähänkin saakka ollut kehittää lehmiä, joiden maidossa olisi voirasvakiloa kohden mahdollisimman vähän valkuaista. Tähän päämäärään on yritetty päästä valitsemalla siitokseen mahdollisimman rasvapitoista maitoa lypsäviä lehmiä. Kuten tunnettua, ei näet maidon valkuaispitoisuus nouse aivan yhtä voimakkaasti kuin rasvapitoisuus, joten valkuaismäärä rasvakiloa kohden pienenee rasvapitoisuuden kohotessa. Siitosvalinnan vaikutus olisi kuitenkin verrattomasti suurempi, jos korkeaa rasvapitoisuntta valittaessa samaraikaisesti valittaisiin alhaista valkuaispitoisuntta.

Tutkimuksessa on tarkasteltu minkälaisia mahdollisuuksia suomalaisessa maatiaiskarjassa olisi mainitunlaiseen siitosvalintaan. Tällöin on lähinnä pyritty selvittämään kuinka pa!jon maidon val- 
kuaispitoisuus muuntelee rasvapitoisuudesta riippumatta. Aineisto käsittää 54 länsisuomalaista maatiaislehmää, joiden maidon rasva- ja valkuaispitoisuus on määritetty kerran kuukaudessa yhden lypsykauden ajan. Näiden analyysitulosten perusteella on todettu seuraavaa:

1. Rasvan ja valkuaisen suhde maidossa ei ole koko lypsykauden ajan samanlainen, vaan se muuttuu siten, että lypsykauden lopussa on valkuaispitoisuus rasvapitoisuuteen verraten suhteellisesti korkeampi kuin lypsykauden alkupuolella (taulukko ja kuvio 1). Lypsykauden rasvapitoisuuden ja valkuaispitoisuuden keskiarvot samoinkuin näiden keskiarvojen välinen suhde on näin ollen jonkinverran riippuvainen poikimisvälin pituudesta. Sen vuoksi on mainitut keskiarvot laskettu vain $2-7$ tuotantokuukauden perusteella.

2. Rasva- ja valkuaispitoisuuden väliseksi vuorosuhdekertoimeksi on, mainittujen $2-7$ tuotantokuukauden keskiarvojen mukaan laskien, saatu $r=+0.60 \pm 0.09$ sekä regressioyhtälöksi $\mathrm{y}=1.53+$ $0.39 \mathrm{x}$, jossa $\mathrm{x}=$ rasvapitoisuus ja $\mathrm{y}=$ valkuaispitoisuus.

3. Yksityiset lehmät saattavat poiketa varsin paljon regressioyhtälön määrittelemästä yleissäännöstä, minkä voi päätellä myös vuorosuhdekertoimen verraten alhaisesta arvosta. Aineistossa esiintyvien äärimmäisten poikkeamien perusteella arvostellen muunteleekin länsisuomalaisten lehmien maidon valkuaispitoisuus ainakin noin yhden prosentin rasvapitoisuudesta riippumatta. Vaikka osa kysymyksessä olevasta muuntelusta ilmeisesti aiheutuu ulkonaisista tekijöistä, on perinnöllisten tekijöiden osuus siinä kuitenkin niin suuri, että näyttäisi olevan suuria mahdollisuuksia kehittää siitosvalinnalla rasvapitoista maitoa lypsäviä lehmiä, joiden maidon valkuaispitoisuus olisi huomattavasti nykyistä keskimäärää alhaisempi. 